\title{
Low abundance of the Endangered timneh parrot Psittacus timneh in one of its presumed strongholds
}

\author{
Simon Valle, Nigel J. Collar, Benjamin Barca \\ Patrick Dauda and Stuart J. Marsden
}

\begin{abstract}
Although both the grey parrot Psittacus erithacus and the recently recognized timneh parrot Psittacus timneh are categorized as Endangered because of harvest for the pet trade and loss of habitat, the latter has a much smaller range and may be largely restricted to a few stronghold areas. In March-April 2018 we surveyed for a total of 114 hours in and around one of these presumed strongholds, the large and well-protected Gola Rainforest National Park, the Sierra Leonean portion of the Gola Transboundary Peace Park. Timneh parrots were encountered at a rate of 0.1 groups/h in the National Park and 0.3 in the buffer zone, indicating densities of $1-3$ individuals per $\mathrm{km}^{2}$. These figures are similar to recent density estimates from the Liberian side of the Peace Park, suggesting that the transboundary population amounts to c. 2,400 individuals inside the Park and an unknown number in the surrounding areas. Densities of the timneh parrot may be generally low even in strongholds, its numbers may be declining steeply, and the global population size is probably lower than previously believed.
\end{abstract}

Keywords Conservation, encounter rate, Gola Rainforest National Park, grey parrot, Psittacus timneh, Sierra Leone, West Africa, wildlife trade

The timneh parrot Psittacus timneh, formerly considered
conspecific with the grey parrot Psittacus erithacus, is
endemic to five countries in the western Upper Guinea
forests of Africa: from Guinea-Bissau and Guinea through
Sierra Leone and Liberia to western Côte d'Ivoire (del
Hoyo \& Collar, 2014). Trapping for the caged bird trade,
combined with high rates of forest loss, has caused a
major decline of the species across its range (Martin et al.,
2014). Although both Psittacus species have recently
been recategorized as Endangered on the IUCN Red List
(BirdLife International, 2o18b), P. timneh has the smaller
range and population. It has probably disappeared from

Simon VAlLe (Corresponding author, (c) orcid.org/0000-0001-9402-1360) School of Natural Sciences, Bangor University, Bangor, Gwynedd, LL57 2UW, UK. E-mail s.valle@bangor.ac.uk

Nigel J. Collar BirdLife International, Cambridge, UK

Benjamin Barca and Patrick Dauda Royal Society for the Protection of Birds/ Gola Rainforest National Park, Kenema, Sierra Leone

Stuart J. Marsden School of Science \& the Environment, Manchester Metropolitan University, Manchester, UK

Received 31 March 2019. Revision requested 2 May 2019.

Accepted 13 June 2019. First published online 4 October 2019. most of its range (Clemmons, 2003; Martin et al., 2014), but a handful of stronghold areas, such as the Bijagós Archipelago in Guinea-Bissau (Lopes et al., 2018a,b) and Sapo National Park in Liberia (Freeman et al., 2019), may retain fairly healthy populations of the species (Dändliker, 1992; Clemmons, 2003; Lopes et al., 2018b). Recent surveys in Côte d'Ivoire, however, have indicated dramatic declines across the country, including in the most important forest protected area, Taï National Park (Marsden et al., 2013; Martin et al., 2014).

The Gola Rainforest National Park is the Sierra Leonean portion of the $1,500 \mathrm{~km}^{2}$ Gola Transboundary Peace Park shared with Liberia. Since the 1990s the National Park has been managed by the national government in partnership with the UK Royal Society for the Protection of Birds, and in 2015 became West Africa's first verified REDD+ project (Barca et al., 2018b). As such, it constitutes one of the largest and best-managed remnants of the Upper Guinean forest in West Africa. Because of the Park's size and management, and because it lies at the heart of the range of $P$. timneh, it was believed to host a significant proportion of the species' global population (BirdLife International, 2018b).

Gola Rainforest National Park (Fig. 1) is dominated by lowland moist evergreen high forest, with an annual rainfall of c. 3,000 mm, mostly falling in a single wet season from May to October (Lindsell et al., 2011). The Park currently consists of two main forest blocks (Gola South, c. $260 \mathrm{~km}^{2}$, and Gola Central, c. $386 \mathrm{~km}^{2}$ ) and a smaller sector (Gola North, c. $54 \mathrm{~km}^{2}$ ), surrounded by a $4-\mathrm{km}$ buffer zone (c. $770 \mathrm{~km}^{2}$ ). Formal agreements with most of the local chiefdoms in the buffer zone support small-scale agriculture, agroforestry and other local livelihood activities aimed at reducing intensive exploitation of the forest. However, illegal gold and diamond prospecting, plus potential concessions to oil palm companies, are an ongoing threat (BirdLife International, 2018a).

From 20 March to 21 April 2018, SV spent 114 hours across 22 days surveying for $P$. timneh in and around Gola Rainforest National Park, including the two main blocks, with 70.8 hours (across 12 days) inside the Park and 43.2 hours (across 16 days) in the buffer zone. Walking surveys occupied $85 \%$ (96 hours) of this time and observations from fixed points $15 \%$ (18 hours). Only one site, Gola South, was surveyed twice from the Sileti guest house, for 60 minutes each time. As dense vegetation prevented safe access and because of time constraints, surveys were conducted only along forest trails (63\% of survey hours) or 


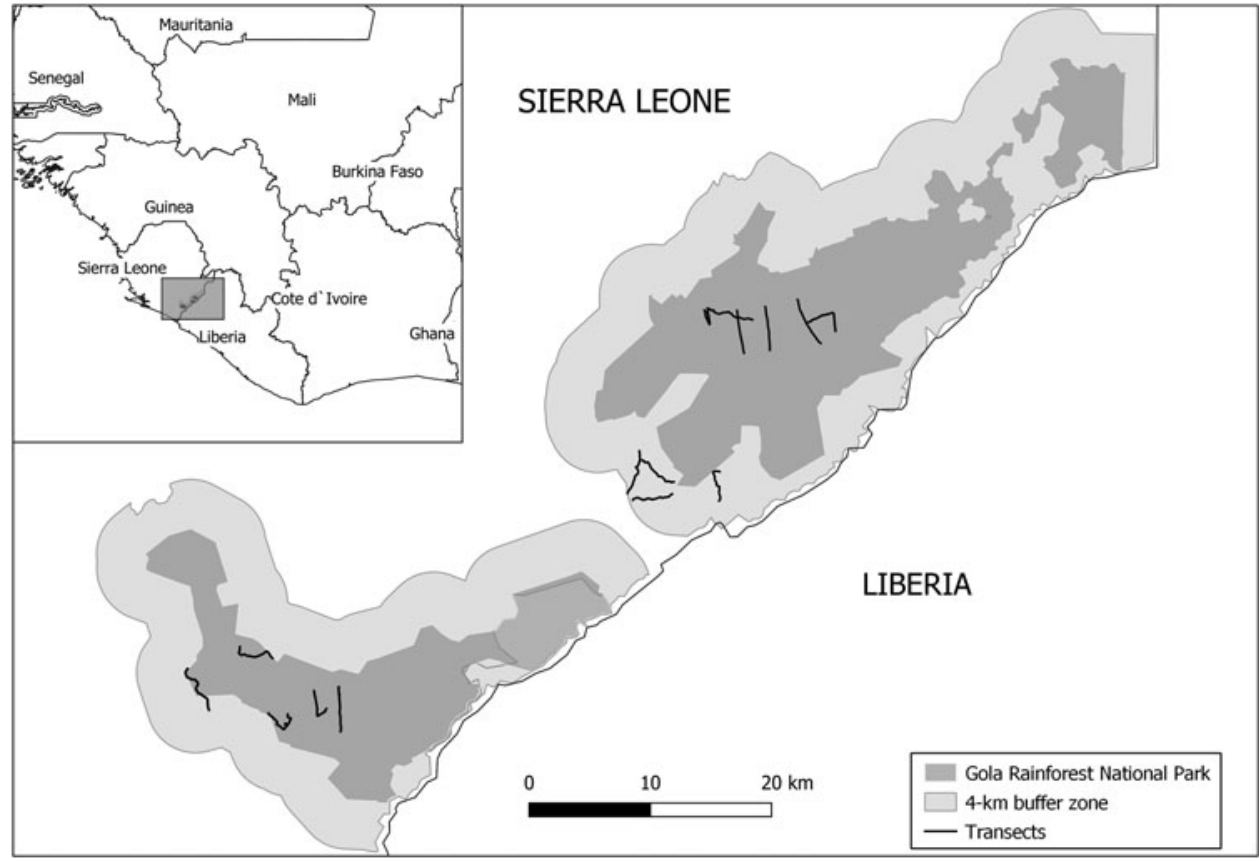

FIG. 1 Gola Rainforest National Park with its $4-\mathrm{km}$ buffer zone and the locations of the transects surveyed for the timneh parrot Psittacus timneh. transects cut for a previous study of primates ( $37 \%$ of survey hours). Surveys were at all hours of the day from morning to dusk (but were suspended during rain or strong winds), and all $P$. timneh heard and seen were counted. Encounter rates (groups/h) were subsequently computed for both the National Park and its buffer zone, and from these numbers density was inferred using the calibration in Marsden et al. (2015). A number of factors (e.g. detectability, observer skill, seasonal variation in group size, local variability in bird mobility) may affect the precision of estimates calculated with this method, resulting in progressively larger confidence intervals at higher densities.

During surveys $P$. timneh was encountered 20 times (on 11 of 22 days; eight times in Gola Rainforest National Park, 12 times in the buffer zone), with a total of 38 individuals recorded (16 in the National Park, 22 in the buffer zone); the Nomo Faama Chiefdom, in the buffer zone, accounted for most encounters and individuals (Table 1). Parrots were only recorded in small groups (mean 1.9 \pm SD o.6). Overall encounter rate was 0.2 groups/h ( 0.1 in the National Park, 0.3 in the buffer zone), which approximates to 1 individual per $\mathrm{km}^{2}$ (95\% CI o-8) in the National Park, and 3 per $\mathrm{km}^{2}$ (95\% CI o-10) in the buffer zone.

This study, although brief, is the most extensive survey of $P$. timneh conducted in and around Gola Rainforest National Park. We found densities much lower than those of reasonably healthy populations of the congeneric grey parrot (Marsden et al., 2015), although they were similar to the 2.2 individuals per $\mathrm{km}^{2}$ found in the Liberian portion of the Transboundary Peace Park where, however, a flock of 70 birds was seen on one occasion (Marsden et al., 2013, 2015). The Gola Rainforest National Park is
TABle 1 Summary of encounters of the parrot Psittacus timneh within Gola Rainforest National Park and its buffer zone during March-April 2018.

\begin{tabular}{lcclc}
\hline & $\begin{array}{l}\text { Survey } \\
\text { hours }\end{array}$ & $\begin{array}{l}\text { Survey } \\
\text { days }\end{array}$ & $\begin{array}{l}\text { No. of } \\
\text { encounters }\end{array}$ & $\begin{array}{l}\text { No. of } \\
\text { individuals }\end{array}$ \\
\hline $\begin{array}{l}\text { Gola Rainforest National Park } \\
\text { Gola Central }\end{array}$ & 29.6 & 5 & 3 & 6 \\
$\begin{array}{l}\text { Gola South } \\
\text { Buffer zone }\end{array}$ & 41.3 & 7 & 5 & 10 \\
$\begin{array}{l}\text { Lalehun } \\
\text { Nyayema }\end{array}$ & 15.0 & 7 & 1 & 2 \\
$\quad$ Community Forest & 5.6 & 1 & 1 & 2 \\
$\begin{array}{l}\text { Nomo Faama } \\
\quad \text { Chiefdom }\end{array}$ & 22.6 & 5 & 10 & 18 \\
\begin{tabular}{l} 
Total \\
\hline
\end{tabular} & 114.1 & 25 & 20 & 38 \\
\hline
\end{tabular}

considered a probable stronghold of the species and has benefited from long-term, effective conservation management, as manifest by its extensive well-preserved forest and healthy populations of frugivore species such as the Vulnerable yellow-casqued hornbill Ceratogymna elata (Valle et al., 2018) and Endangered Upper Guinea red colobus Piliocolobus badius (Barca et al., 2018a). We do not know whether $P$. timneh has always had a low density in the National Park or has suffered recent declines, but the sparse evidence points to the latter. Anecdotal reports of large numbers of birds formerly roosting in the Nomo Faama Chiefdom (PD, pers. obs.) and of previous heavy trapping suggest that harvest for the pet trade may have played a major role in reducing the area's population. We found no indication that parrots are currently trapped there for the pet trade. Surveys in 2006 yielded similarly 
low encounter rates (Dowsett-Lemaire \& Dowsett, 2007) and in 2011 P. timneh was recorded at only one locality outside the National Park, on the border with Liberia (Demey, 2012). The highest number of encounters was recorded in the Nomo Faama Chiefdom; this could be because exploitation there is more focused on gold mining than on agriculture (i.e. disturbance and forest clearing are less extensive). There were a similar number of records in the National Park and its buffer zone, suggesting that a matrix of habitats may be beneficial for the species (Valle et al., 2017), although we do not yet know how the species uses each area (e.g. for feeding, roosting or nesting).

Given the large area of protected forest within Gola Transboundary Peace Park $\left(1,500 \mathrm{~km}^{2}\right)$ and its buffer zones, even low-density estimates (mean density 1.6 parrots per $\mathrm{km}^{2}$ ) indicate a reasonable population size. We suggest that the population within the Peace Park itself may be c. 2,400 individuals, with a currently unknown but perhaps substantial number in the buffer zones around the Park. However, the true population size could be smaller because of the imprecision associated with our method. There is strong evidence that the species has disappeared from the majority of its range (Martin et al., 2014), and the future for wild $P$. timneh rests largely in Gola, along with the Bijagós Islands, Guinea-Bissau (where there are c. 1,000 individuals: Lopes et al., 2018a,b) and Sapo National Park, Liberia (c. 37,00o individuals: Freeman et al., 2019). Although it now seems likely that the global population is lower than the estimated $>100,000$ (BirdLife International, 2018b), further research on the species in Liberia and Sierra Leone, within and outside protected areas, including measures to boost productivity if further evidence emerges of recent trapping, is a priority.

Acknowledgements We thank Eric Vignot and the Parrot Wildlife Foundation for generously funding this research, Mohamed Nyallay for assistance in the field, Brima Sheku Turay and Pietro Sandini for support with logistics, Gola Rainforest National Park for permission to carry out research, and two anonymous reviewers for their valuable comments.

Author contributions Study design and fieldwork: SV, SM; data analysis: SV, SM; writing: SV, NC, BB, SM.

\section{Conflicts of interest None.}

Ethical standards This research abided by the Oryx guidelines on ethical standards.

\section{References}

Barca, B., Tayleur, C., \& Turay, B.S. (2018a) Recovery of Upper Guinea Red Colobus Piliocolobus badius and Other Primates in Gola Rainforest National Park, Eastern Sierra Leone. Presented at the 27th International Primatological Society Congress 19-25 August 2018. Nairobi, Kenya.
Barca, B., Turay, B.S., Kanneh, B.A., \& Tayleur, C. (2018b) Nest ecology and conservation of Western Chimpanzees (Pan troglodytes verus) in Gola Rainforest National Park, Sierra Leone. Primate Conservation, 32, 133-139.

Birdife International (2018a) Important Bird Areas Factsheet: Gola Forests. Http://www.birdlife.org [accessed 8 February 2019].

BirdLife International (2018b) Species Factsheet: Psittacus timneh. Http://datazone.birdlife.org/species/factsheet/22724813 [accessed 8 February 2019].

Clemmons, J. (2003) Status Survey of the African Grey Parrot (Psittacus erithacus timneh) and Development of a Management Program in Guinea and Guinea-Bissau. CITES Secretariat, Geneva, Switzerland.

Dändliker, G. (1992) Le Perroquet Gris (Psittacus erithacus) en Guinée. Evaluation des Populations, Contribution à la Biologie, Étude de l'Exploitation Commerciale et Recommandations pour la Gestion. Report sur le Projet CITES S-30. Unpublished report. CITES Secretariat, Geneva, Switzerland.

DEL Hoyo, J. \& Collar, N.J. (2014) Illustrated Checklist of the Birds of the World. Lynx Edicions, Barcelona, Spain.

Demey, R. (2012) Ornithological Survey of the Transboundary Area Sierra Leone/Liberia of Gola Forest: 21 February-31 March 2011. Unpublished report.

Dowsett-Lemaire, F. \& Dowsett, R. (2007) Faunistic Survey of Gola Forest (Sierra Leone) in January-February 2007, with an Emphasis on Birds. Unpublished Report. RSPB, Sandy, UK.

Freeman, B., Dami, F.D. \& Molokwu-Odozi, M. (2019) Status of globally threatened birds of Sapo National Park, Liberia. Ostrich, 90, 19-24.

Lindsell, J.A., Klop, E. \& Siaka, A.M. (2011) The impact of civil war on forest wildlife in West Africa: mammals in Gola Forest, Sierra Leone. Oryx, 45, 69-77.

Lopes, D.C., Martin, R.O., Henriques, M., Monteiro, H., Cardoso, P., Tchantchalam, Q. et al. (2018a) Combining local knowledge and field surveys to determine status and threats to timneh parrots Psittacus timneh in Guinea-Bissau. Bird Conservation International, published online 3 October 2018.

Lopes, D.C., Martin, R.O., Henriques, M., Monteiro, H., Regalla, A., Tchantchalam, Q. et al. (2018b) Nest-site characteristics and aspects of the breeding biology of the Endangered timneh parrot Psittacus timneh in Guinea-Bissau. Ostrich, 89, 33-40.

Marsden, S.J., Loqueh, E., Takuo, J.M., Hart, J.A., Abani, R., Ahon, D.B. et al. (2013) A protocol to allow density estimation and monitoring of the heavily traded grey parrots across their huge African ranges. In Strengthening Capacity for Monitoring and Regulation of International Trade of African Grey Parrot (ed. CITES), pp. 1-18. CITES Secretariat, Geneva, Switzerland.

Marsden, S.J., Loqueh, E., Takuo, J.M., Hart, J.A., Abani, R., Aнол, D.B. et al. (2015) Using encounter rates as surrogates for density estimates makes monitoring of heavily-traded grey parrots achievable across Africa. Oryx, 50, 617-625.

Martin, R.O., Perrin, M.R., Boyes, R.S., Abebe, Y.D., Annorbah, N.D., Asamoah, A. et al. (2014) Research and conservation of the larger parrots of Africa and Madagascar: a review of knowledge gaps and opportunities. Ostrich, 85, 205-233.

Valle, S., Collar, N.J., Harris, W.E. \& Marsden, S.J. (2017) Spatial and seasonal variation in abundance within an insular grey parrot population. African Journal of Ecology, 55, 433-442.

Valle, S., Collar, N. \& Marsden, S. (2018) Abundance and Distribution of Timneh Parrot Psittacus timneh in and Around Gola Rainforest National Park, Sierra Leone. Unpublished report. Parrot WildLife Foundation, Crécy-la-Chapelle, France. 